\title{
Analysis of the temporal space distribution of reported Dengue cases: a systematic review of the literature
}

\author{
Andrezza Fabianni Pedrosa dos Santos Lima ${ }^{1}$, Emilly Tainá Batista da Silva ${ }^{2}$, Emivaldo Batista da \\ Silva ${ }^{3 *}$, Joana Bulhões Alvares da Silva Lima ${ }^{4}$, Edivânia Almeida Guimarães ${ }^{5}$, Ana Jhoice de \\ Santana $^{6}$, Ana Greice Borba Leite ${ }^{7}$, Suelane Michelly Ferreira Alves ${ }^{8}$, Simara Lopes Cruz Damazio ${ }^{9}$, \\ Islane Cristina Martins ${ }^{10}$, Antônio Flaudiano Bem Leite ${ }^{11}$, Amanda Steffany da Silva Lira ${ }^{12}$, Váleria \\ Bezerra da Silva ${ }^{13}$, Emanuella Barros de Souza Oliveira Alvares ${ }^{14}$
}

1,8,12,13 Department of Nutrition, University Center of Vitória de Santo Antão - UNIVISA, Vitoria de Santo Antão

2 Department of Biomedicine, Post-Graduation in Laboratory Clinical Microbiology (ASCES- UNITA) Caruaru - PE

3.4 Department of Pharmaceutical Sciences, University Center of Vitória de Santo Antão - (UNIVISA) Vitória de Santo Antão, Brazil.

5 Department of Pharmaceutical Sciences, Master's degree in Pharmaceutical Sciences - Federal University of Alagoas UFAL

6 Department of Biomedicine, Center for Biomedical Sciences, Federal University of Pernambuco - UFPE, Recife, Brazil.

7 Department of Veterinary Medicine Rural University of Pernambuco, Recife - PE

9 Department of Bachelor's Degree in Nursing Federal University of Pernambuco, Vitória de Santo Antão, PE.

10.11 Department of Collective Health Federal University of Pernambuco, Vitória de Santo Antão, PE, Brazil.

14 Department of Biology, Center for Biological Sciences, Professor of the Degree Course in Biology, University Center of Vitória de Santo Antão (UNIVISA), Vitória de Santo Antão, Brazil

E-mail adresses: andrezzafpslima@hotmail.com1 (Andrezza Fabianni Pedrosa dos Santos Lima), emilly.taina@hotmail.com2 (Emilly Tainá Batista da Silva), emivaldobatista4@gmail.com3 (Emivaldo Batista da Silva), joanafarmacia2018@gmail.com4 (Joana Bulhões Alvares da Silva Lima), edvaniaaguimaraes@gmail.com5 (Edivânia Almeida Guimarães), jhoiceferreira15@gmail.com6 (Ana Jhoice de Santana), ag_mv530@hotmail.com7 (Ana Greice Borba Leite), llanealves82@gmail.com8 (Suelane Michelly Ferreira Alves), simara.cruz@ufpe.br9 (Simaria Lopes Cruz Damazio), islanemartins@gmail.com10 (Islane Cristina Martins), afbl@outlook.com.br11 (Antônio Flaudiano Bem Leite), amandasteffany09@icloud.com12 (Amanda Steffanny da Silva Lira), valeriabezerra.s@hotmail.com13 (Valéria Bezerra da Silva), emanuella.barros@hotmail.com14 (Emanuella Barros de Souza Oliveira Alvares)

${ }^{*}$ Corresponding author

\section{To cite this article:}

Lima, A.F.P.S.; Silva, E.T.B.; Silva, E.B.; Lima, J.B.A.S.; Guimarães, E.A.; Santana, A.J.; Leite, A.G.B.; Alves, S.M.F.; Damazio, S.L.C.; Martins, I.C.; Leite, A.F.B.; Lira, A.S.S.; Silva, V.B.; Álvares, E.B.S.O. Analysis of the temporal space distribution of reported Dengue cases: a systematic review of the literature. International Journal of Sciences. Vol. 3, No. 1, 2022, pp.35-43. ISSN 2763-5392.

Received: 11 24, 2021; Accepted: 12 26, 2021; Published: 01 15, 2022

\begin{abstract}
Dengue is considered an infectious pathogenesis of acute evolution, which in recent years has seen an increase in the number of cases, constituting a serious public health problem in the world, especially in tropical countries, where environmental conditions favor the development and proliferation of Aedes aegypti, the main vector mosquito. This study aimed to randomizer a systematic review of the literature in order to understand how the temporal space distribution of dengue cases occurs. A survey of the literature was carried out in July 2019, in the periodic databases CAPES and Google Scholar. The descriptors used were: "Temporal space distribution" AND "Dengue" AND "Geoprocessing". A total of 10 articles were selected and included according to the eligibility criteria. The inclusion criteria were articles in English, Spanish and Portuguese, in the last five years, involving analysis of the temporal space distribution of reported dengue cases. Geoprocessing techniques and geostatistics have made it possible for ecological studies to make more evident the participation of the conjunction of factors, including contextual factors, in the determination of the disease by incorporating effects of the specific characteristics of each social space. The sand-time analyses of dengue cases allowed the knowledge of the geographic distribution of the disease. As well as the techniques of analysis of time trends defined as useful areas in all studies allowed the development and construction of practices applied in the process of prevention and health promotion.
\end{abstract}

Keywords: Geoprocessing; Aedes aegypti; epidemiology. 
2 Lima, A.F.P.S.; Silva, E.T.B.; Silva, E.B.; Lima, J.B.A.S.; Guimarães, E.A.; Santana, A.J.; Leite, A.G.B.; Alves, S.M.F.; Damazio, S.L.C.; Martins, I.C.; Leite, A.F.B.; Lira, A.S.S.; Silva, V.B.; Álvares, E.B.S.O. Analysis of the temporal space distribution of reported Dengue cases: a systematic review of the literature...

\section{Introduction}

Dengue is transmitted by viruses of type (RNA virus) and is considered an infectious pathogenesis of acute evolution. The human being is infected through the bite of the female insect Aedes aegypti. It has variable signs and symptoms, presenting symptomatic oligo forms, classical forms (febrile) and severe hemorrhagic forms, and may even present hypopovoic cardiovascular syndrome (Xavier et al., 2014). It is described as one of the most relevant tropical diseases worldwide due to its high incidence. Related to climatic variables and socioeconomic, socio-environmental and political conditions, which favor the proliferation of the entire vector in the territory (Carvalho et al., 2017).

According to the World Health Organization (WHO), 2015 was the year with the highest epidemic peaks in brazil' dengue disease, surpassing the epidemiological records consolidated in previous years, 2010 and 2013, described as the period in which notifications presented a categorization pattern. Once epidemiological investigation occurs, reported cases can be completed as: confirmed cases, discarded cases, inconclusive and ignored cases. Inadequate filling out of forms or the presence of gaps in their production and management can directly affect the quality of an information system (Brazil, 2016a).

However, several environmental, individual, vector and virus factors directly influence the incidence of asymptomatic infections. The occurrence of short-term nonspecific fever, accompanied by pharyngitis, rinitis and mild cough, has its highest concentration in lactating and preschoolers. Occasionally it is possible that this febrile condition pops associated with maculopapular eruption, impairing its diagnosis exclusively in clinical databases (Brazil, 2016b).

On the other hand, space is no longer considered only as a geographical delimitation, beginning to contemplate the social, economic and political relationships and dynamics that have changed it throughout history. In this sense, the development of spatial analysis represented a valuable tool for understanding how a given context affects the health of the population and population groups (Kleinbaum et al., 1998). There is a set of time trend analysis techniques that may be useful in epidemiological studies and their more frequent use will certainly lead to new developments in health prevention and promotion practices. Likewise, geoprocessing techniques and analysis models for spatial distributions can provide new tools for describing diseases in population. The conceptual refinement of the categories used for the characterization of the most affected groups may also increase the explanatory power of descriptive studies (Clayton \& Hill, 1993).

However, in recent years, there has been an increase in the number of cases, constituting a serious public health problem in the world, especially in tropical countries, where environmental conditions favor the development and proliferation of Aedes aegypti, the main vector mosquito: acute febrile disease, of viral etiology and benign evolution in the classical form, and when presented in hemorrhagic form.
Considering the various studies that demonstrate and affirm the relationship of environmental determinants and climatic factors under the dynamics of endemic smaemias, and knowing the pertinence and magnitude of dengue in Brazil and worldwide, the development of a systematic review of the literature becomes relevant. The present study aimed to conduct a systematic review of the scientific literature in order to understand how the temporal space distribution of dengue cases occurs.

\section{Methodology}

A survey of the literature was carried out in July 2019 , in the periodic databases CAPES and Google Scholar. The descriptors used were: "Temporal space distribution" AND "Dengue" AND "Geoprocessing" in both databases. A total of 10 articles were selected and included according to the eligibility criteria according to Figure 1. Inclusion criteria were: articles in English, Spanish and Portuguese in the last five years, involving analysis of the temporal space distribution of reported dengue cases. Exclusion criteria were literature review articles or meta-analysis.

\section{Results}

The results of the present study are found in Table 1.

\section{Discussion}

Dengue is characterized as a serious public health problem, responsible for about 100 million sick peoplefor years7, making it necessary to implementincentive programs to control and combat its vector, Aedes aegypti (Fernandes \& Gomes, 2018).

According to reports ${ }^{3}$, dengue epidemics in Brazil have emerged since 1846, being the first concrete indication of the occurrence of an epidemic in 1982, when the serotypes DENV1 and DENV4 were isolated in the municipality of Boa Vista (RR). The year 2015 showed a total of 815,903 cases reported for dengue disease in Brazil (Barbosa et al., 2015). The World Health Organization highlighted that 2015 presented superior epidemiological records related to the number of notifications made for dengue, offering a worldwide picture of an increase in the incidence rate of this disease (Brasil, 2016a). There is a higher concentration of notification of serotype DENV1 (64\% and $82 \%$, respectively) followed by the SEROTYPE DENV4 $(32 \%$ and $16 \%$, respectively) in Brazil in the years 2014 and 2015 (Brazil, 2016a, 2016b).

According to the records consolidated in 2015, $1,649,008$ dengue cases were requested in the country. The Southeast region had the highest number of reported cases $(1,026,226$ cases, $62.20 \%)$, followed by the Northeast (311,519 cases, $18.9 \%)$, Midwest (220,966 cases, $13.4 \%)$, South $(56,187$ cases, $3.4 \%)$ and North (34,110 cases, $2.1 \%)$. From January to September 2016 (up to the 37th 
epidemiological week), 1,438,624 confirmed dengue cases were reported to the Ministry of Health nationwide, 762 of severe dengue and 7,449 dengue with alarm signs (Brazil, 2016b).

In reference to the analysis of the temporal space distribution of reported dengue cases, the correct application of the geoprocessing and statistical analysis technique directly contribute to the interpretation of the factors that implied the occurrence of the disease (Skaba et al., 2004).

On the result of the time series performed by Defavari et al. (2017), the increase in the incidence rate of dengue, allowed, alert the authorities to a probable endemic reaction of the disease in the studied area.

However, municipalities should be cautious when applying the geoprocessing tool as a unit of analysis, especially when it comes to investigating the behavior of a disease described in a time series. The spatial statistical analysis is considered in this context, responsible for identifying probable correlations of the event and space (Carvalho et al., 2018).

As for the spatial association of dengue, Defavari et al. (2017) demonstrates that during the years 2011, 2012 and 2013 there was a spatial association of dengue with neighborhoods, representing an increase in the incidence rate of the disease. There is a spatial dependence between the nearest neighborhoods. With regard to spatial distribution analysis, the Kernel estimator is considered a nonparametric method for estimating density curves, where each observation is weighted by distance relative to a central value, the nucleus.

Performing a count of all points within a region of influence, pondering them by the distance of each one in relation to the location of interest. A prominent instrument for planning actions, since it can and should be used to better understand the factors that contribute to the occurrence of dengue (Barbosa \& Lourenço, 2010).

Geoprocessing techniques and geostatistics have made it possible for ecological studies to make more evident the participation of the conjunction of factors, including contextual factors, in the determination of the disease by incorporating effects of the specific characteristics of each social space. Although with limitations, this approach contributes so that epidemiology can integrate, dialectically, the social with the natural, as supported by the thinkers of social epidemiology (Skalinski et al., 2019).

According to Skaba et al. (2004), the georeferencing techniques applied properly can consolidate an evaluation of the spatial distribution of assertive dengue, leading to an understanding and interpretation of factors related to the occurrence of reported cases. However, it is necessary that the storage of the data in the information systems is compiled correctly.

In a study conducted by Flauzino et al. (2009), in the city of Niterói, RJ, applied the Kernel estimator, it is suggested that after the use of kernel density and proportion, the areas that present the highest occurrence of dengue may be related to the social vulnerability of individuals.
It is noteworthy that Scandar et al. (2010), states that the use of data geoprocessing can directly assist in the perception and analysis of data, ingesting and deliberating the construction of tools to support the fight against epidemics.

\section{Conclusion}

The sand-time analyses of dengue cases allowed the knowledge of the geographic distribution of the disease, identifying non-homogeneous patterns, with concentrations in vulnerable areas: social, economic and environmental. As well as the techniques of analysis of time trends defined as useful areas in all studies allowed the development and construction of practices applied in the process of prevention and health promotion. Similarly, geoprocessing trends and analysis models for spatial distributions provided tools for the detailed description of dengue.

\section{References}

[1] Araújo VEM, Bezerra JMT, Amâncio FF, Passos VMA, Carneiro M. Aumento da carga de dengue no Brasil e unidades federadas, 2000 e 2015: análise do Global Burden of Disease Study 2015. Rev Bras Epidemiol 20(1):205-216, 2017.

[2] Barbosa GL, Lourenço RW. Análise da distribuição espaço-temporal de dengue e da infestação larvária no município de Tupã, Estado de São Paulo. Rev Soc Bras Med Trop 43(2):145-51, 2010.

[3] Barbosa JR, Barrado JCS, Zara ALSA, Siqueira Júnior JB. Avaliação da qualidade dos dados, valor preditivo positivo, oportunidade e representatividade do sistema de vigilância epidemiológica da dengue no Brasil, 2005 a 2009. Epidemiol Serv Saude 24(1):49-58, 2015.

[4] Brasil. Ministério da Saúde. Secretaria de Vigilância em Saúde. Monitoramento dos casos de dengue, febre de chikungunya e febre pelo vírus Zika até a Semana Epidemiológica 3. Bol Epidemiol 47(6):1-7, 2016a.

[5] Brasil. Ministério da Saúde. Secretaria de Vigilância em Saúde. Monitoramento dos casos de dengue, febre de chikungunya e febre pelo vírus Zika até a Semana Epidemiológica 37. Bol Epidemiol 47(34):1-10, $2016 \mathrm{~b}$.

[6] Carvalho CO, Rabello RS, Thomé SMG. Distribuição Espacial da Dengue no Estado do Rio de Janeiro no período de 2001 a 2012. HYGEIA. Hygeia 14(27): 108-123, 2018.

[7] Carvalho S, Magalhães MAFM, Medronho RA. Análise da distribuição espacial de casos da dengue no município do Rio de Janeiro, 2011 e 2012. Rev Saude Publica 51:1-10, 2017. 
4 Lima, A.F.P.S.; Silva, E.T.B.; Silva, E.B.; Lima, J.B.A.S.; Guimarães, E.A.; Santana, A.J.; Leite, A.G.B.; Alves, S.M.F.; Damazio, S.L.C.; Martins, I.C.; Leite, A.F.B.; Lira, A.S.S.; Silva, V.B.; Álvares, E.B.S.O. Analysis of the temporal space distribution of reported Dengue cases: a systematic review of the literature...

[8] Clayton D, Hill M. Statistical models in epidemiology. Oxford. Oxford Science Publications, 1993.

[9] Defavari ER, Fonseca EP, Silva RP, Moreira RS, Pereira $\mathrm{AC}$, Batista MJ. Análise espacial da incidência da dengue em um município de médio porte do estado de São Paulo de 2008 a 2015. Rev Saúde Col 7(3):10-17, 2017.

[10] Fernandes LA, Gomes MMF. Análise dos dados do SINAN sobre dengue nos municípios da área metropolitana de Brasília (AMB). Braz J Hea Rev 1(2):314-322, 2018.

[11] Flauzino RF, Souza-Santos R, Barcellos C, Gracie R, Magalhães MAFM, Oliveira RM. Heterogeneidade espacial da dengue em estudos locais, Niterói, RJ. Rev Saude Publica 43(6):1035-43, 2009.

[12] Kleinbaum DG, Kupper LL, Muller KE. Applied regression analysis and other multivariate methods. Boston. PWS Kent Publishing Company, 1988.

[13] Scandar SAS, Vieira P, Cardoso Júnior RP, Silva RA, Papa M, Sallum MAM. Dengue em São José do Rio Preto, Estado de São Paulo, Brasil, 2005: fatores entomológicos, ambientais e socioeconômicos. Bol Epidemiol Paulista 7(81):4-16, 2010.

[14] Skaba DA, Carvalho MS, Barcellos C, Martins PC, Terron SL. Geoprocessamento dos dados da saúde: o tratamento dos endereços. Cad Saude Publica 20(6):1753-6, 2004.

[15] Skalinski LM, Costa MCN, Teixeira MGL. Contribuições da análise espacial para a compreensão da dinâmica de transmissão da dengue: revisão integrativa. J Health Biol Sci 7(1):53-63, 2019.

[16] Xavier AR, Freitas MSL, Loureiro FM, Borghi DP, Kanaan S. Manifestações clínicas na dengue: diagnóstico laboratorial. J Bras Med. 102(2):7-14, 2014.

\section{Attachments}

\begin{tabular}{c|c|c|c|c|c|c}
\multicolumn{2}{c}{ Table 1 - Statement of the articles that make up the Integrative Review } \\
\hline \multirow{2}{*}{ N } & Date & Title & Authors & Periodic & Goals & Findings
\end{tabular}$\quad 2018$

\begin{tabular}{|c|c|c|c|c|}
\hline $\begin{array}{l}\text { and Zika } \\
\text { arboviru } \\
\text { ses in } \\
\text { the state } \\
\text { of Rio } \\
\text { Grande } \\
\text { do } \\
\text { Norte, } \\
\text { Brazil }\end{array}$ & & $\begin{array}{l}\text { Grande do } \\
\text { Norte. }\end{array}$ & $\begin{array}{l}\mathrm{n} \text { of } \\
\text { dengue, } \\
\text { Chikungun } \\
\text { ya and } \\
\text { Zika cases } \\
\text { in the State } \\
\text { of Rio } \\
\text { Grande do } \\
\text { Norte }\end{array}$ & $\begin{array}{l}\text { time series } \\
\text { was the } \\
\text { Metropolit } \\
\text { an region } \\
\text { (VII) with } \\
93,424 \\
\text { reported } \\
\text { cases. The } \\
\text { year in } \\
\text { which the } \\
\text { three } \\
\text { arboviruse } \\
\text { s were } \\
\text { most } \\
\text { affected } \\
\text { was 2016 } \\
\text { and the } \\
\text { health } \\
\text { region } \\
\text { with the } \\
\text { most } \\
\text { confirmed } \\
\text { cases in } \\
\text { the period } \\
2015-2017 \\
\text { was the } \\
\text { Region of } \\
\text { Mossoró } \\
\text { (II), with a } \\
\text { total of } \\
12,253 \\
\text { confirmed } \\
\text { cases of } \\
\text { dengue, } \\
\text { Chikungu } \\
\text { nya and } \\
\text { Zika. }\end{array}$ \\
\hline $\begin{array}{l}\text { Spatial } \\
\text { Distribut } \\
\text { ion of } \\
\text { Dengue } \\
\text { in the } \\
\text { State of } \\
\text { Rio de } \\
\text { Janeiro } \\
\text { from } \\
2001 \text { to } \\
2012\end{array}$ & $\begin{array}{l}\text { Camila de } \\
\text { Oliveira } \\
\text { Carvalho; } \\
\text { Renata dos } \\
\text { Santos } \\
\text { Rabello }\end{array}$ & $\begin{array}{l}\text { HYGEIA - } \\
\text { Brazilian } \\
\text { Journal of } \\
\text { Medical } \\
\text { and Health } \\
\text { Geography }\end{array}$ & $\begin{array}{l}\text { To analyze } \\
\text { the spatial } \\
\text { distributio } \\
\mathrm{n} \text { of } \\
\text { dengue } \\
\text { cases in } \\
\text { the state of } \\
\text { Rio de } \\
\text { Janeiro, } \\
\text { from 2001 } \\
\text { to } 2012 \text {, in } \\
\text { order to } \\
\text { identify } \\
\text { the regions } \\
\text { with the } \\
\text { greatest } \\
\text { risks for } \\
\text { the } \\
\text { occurrence } \\
\text { of the }\end{array}$ & $\begin{array}{l}\text { According } \\
\text { to the } \\
\text { incidence } \\
\text { rates } \\
\text { calculated } \\
\text { for the } \\
\text { study } \\
\text { period, the } \\
\text { municipali } \\
\text { ties with } \\
\text { the highest } \\
\text { number of } \\
\text { notificatio } \\
\text { ns are } \\
\text { located in } \\
\text { the } \\
\text { BaixadaS } \\
\text { Litorâneas } \\
\text { and Norte } \\
\text { Fluminens }\end{array}$ \\
\hline
\end{tabular}




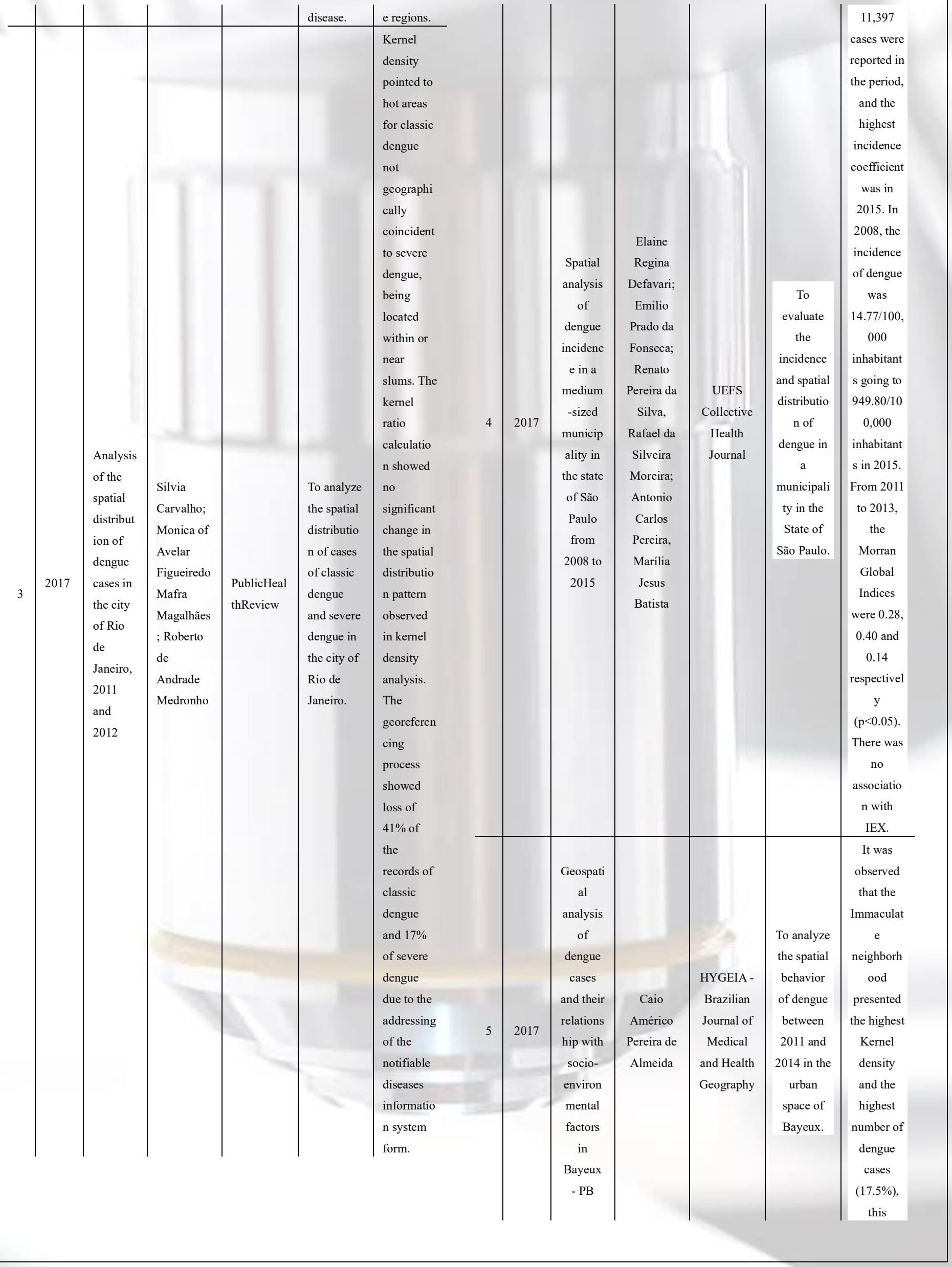


6 Lima, A.F.P.S.; Silva, E.T.B.; Silva, E.B.; Lima, J.B.A.S.; Guimarães, E.A.; Santana, A.J.; Leite, A.G.B.; Alves, S.M.F.; Damazio, S.L.C.; Martins, I.C.; Leite, A.F.B.; Lira, A.S.S.; Silva, V.B.; Álvares, E.B.S.O. Analysis of the temporal space distribution of reported Dengue cases: a systematic review of the literature...

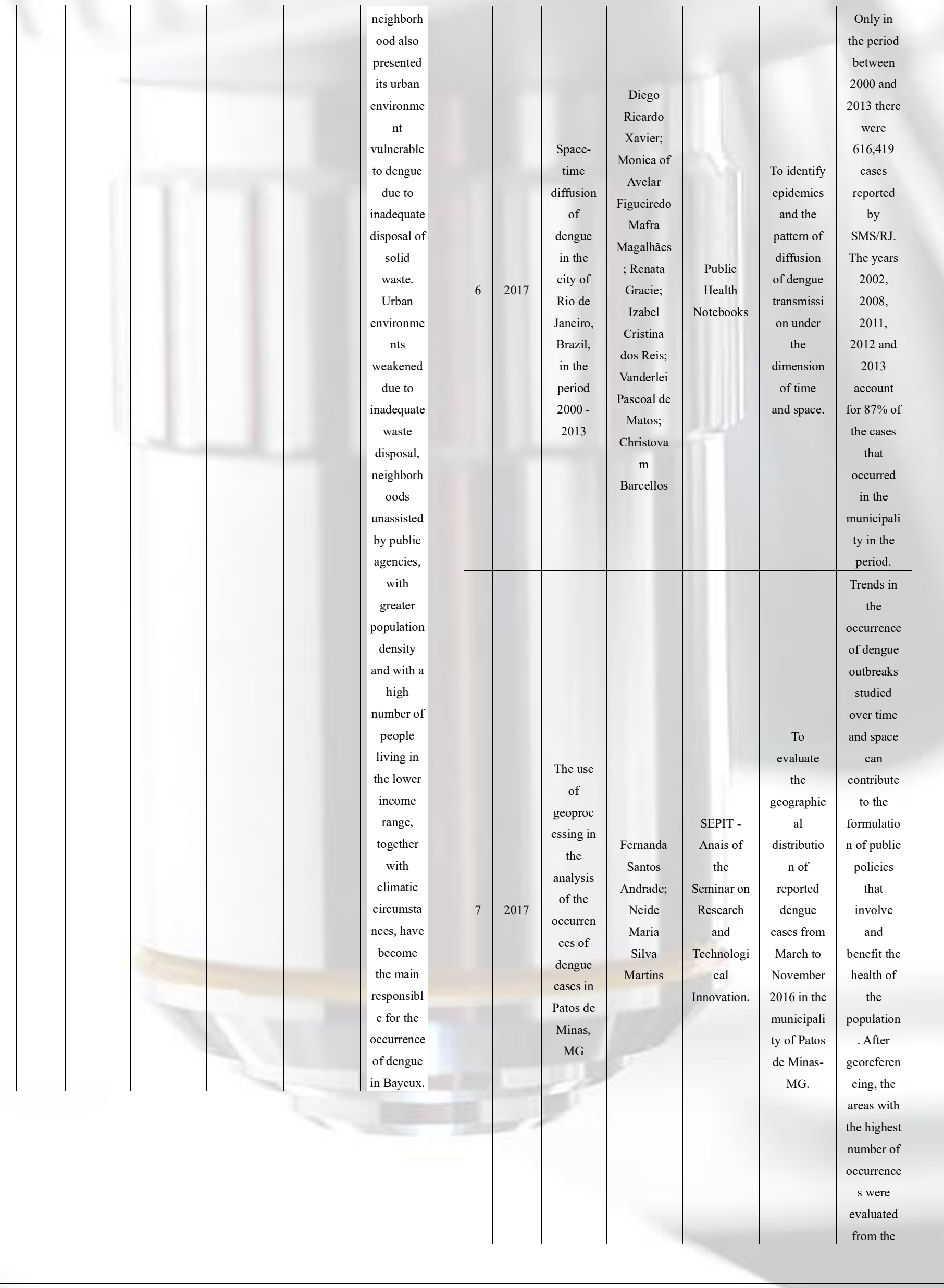




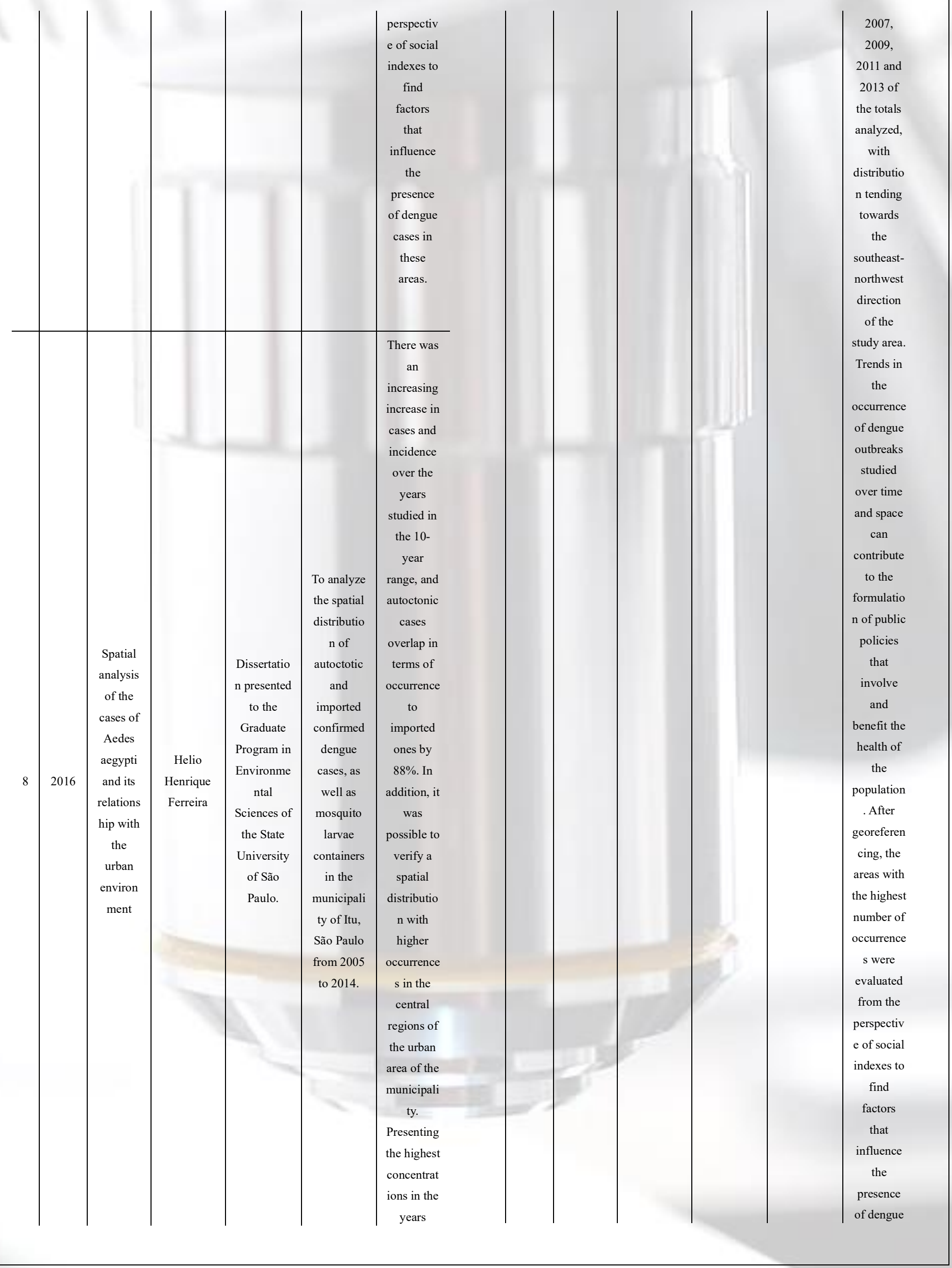


8 Lima, A.F.P.S.; Silva, E.T.B.; Silva, E.B.; Lima, J.B.A.S.; Guimarães, E.A.; Santana, A.J.; Leite, A.G.B.; Alves, S.M.F.; Damazio, S.L.C.; Martins, I.C.; Leite, A.F.B.; Lira, A.S.S.; Silva, V.B.; Álvares, E.B.S.O. Analysis of the temporal space distribution of reported Dengue cases: a systematic review of the literature...

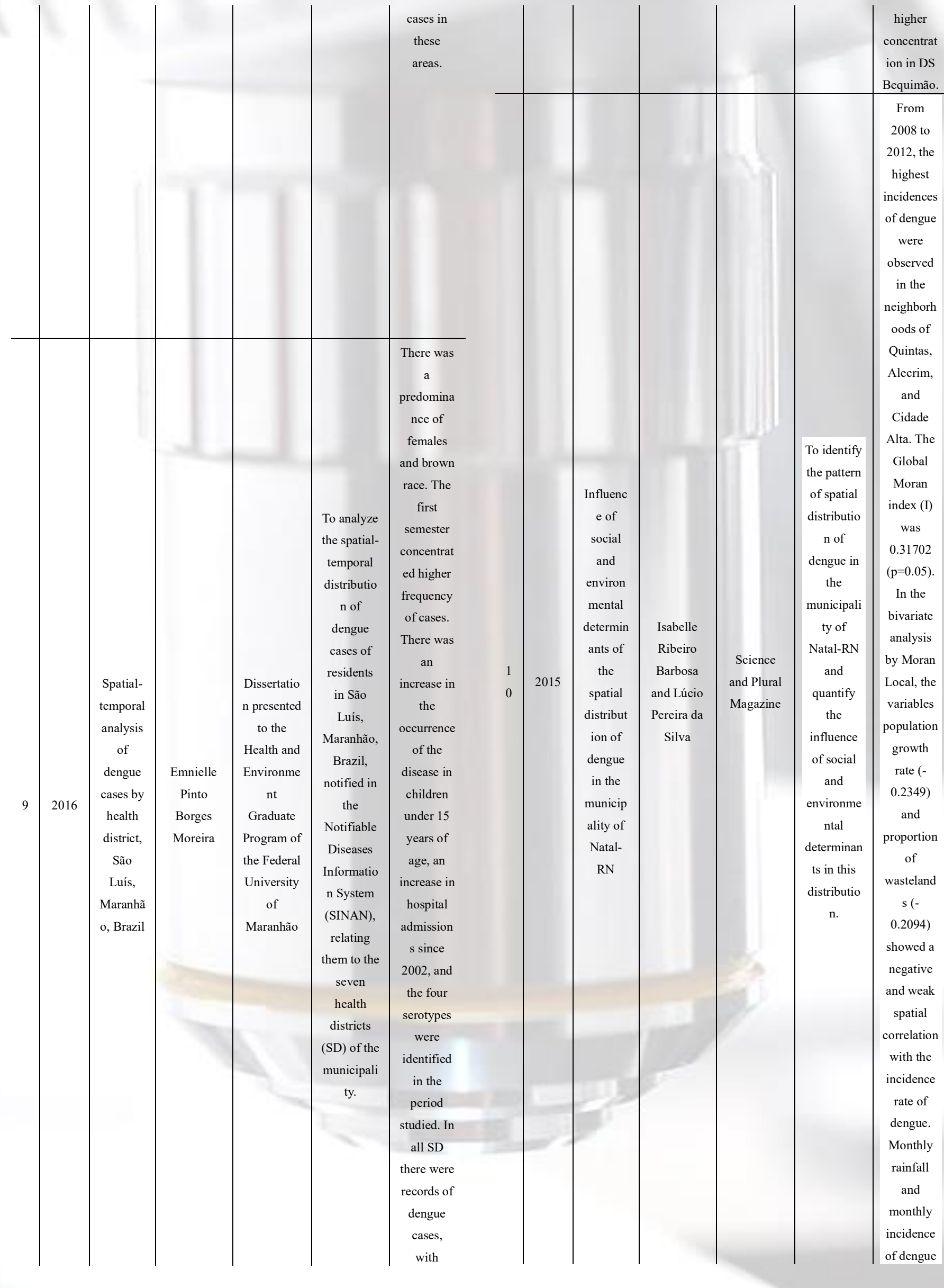




$|\downarrow| ⿰ \mid \begin{gathered}\text { in the city } \\ \text { of Natal } \\ \text { showed a } \\ \text { weak } \\ \text { correlation } \\ (\mathrm{r}=0.399) .\end{gathered}$

